\title{
Linking Ethics and Economic Growth: a Comment on Hunt
}

\author{
Nicolai J. Foss ${ }^{1}$
}

ABSTRACT

Hunt (2012) builds on his work concerning ethics and resource-advantage theory to link personal ethical standards, societal norms, and economic growth but offers few details concerning the precise mechanisms that link ethics and growth. This comment suggests a number of such mechanisms - for example, the influence of prevailing ethical norms on the aggregate elasticity of substitution and, therefore, total factor productivity and growth.

KEY WORDS: $\quad$ ethics, trust, competition, productivity, economic growth, resource-advantage theory,

JEL Classification: D40, O40

${ }^{1}$ Copenhagen Business School; Norwegian School of Economics and Business Administration, Norway

\section{Introduction}

In "Trust, Personal Moral Codes, and the ResourceAdvantage Theory of Competition: Explaining Productivity, Economic Growth, and Wealth Creation," Professor Shelby D. Hunt addresses what should rightly be one the key questions in social science - namely, the aggregate implications of ethical beliefs and judgments that, while having an obvious collective-level dimension, are in the end held by individuals. Important philosophers and economists may have been preoccupied with this issue - David Hume, Adam Smith, Frank Knight and Friedrich Hayek come to mind - but one rarely to witnesses a management (marketing) scholar offer important reflections on the matter. Hunt rightly notes that "...a consensus is developing that societallevel moral codes that promote social trust promote wealth creation" and sets out to "...contribute to our understanding of the nature of the kinds of societallevel moral codes that are thought to promote social

-

Corespondence concerning this article should be addressed to: njf.smg@cbs.dk trust," as well as examine the mechanisms that link trust-promoting, societal-level moral codes to wealth creation (Hunt, 2012, p. 1). He seeks to account for these mechanisms in terms of the resource-advantage theory of firms and competition, which he has pioneered in marketing research and may be loosely described as resource-based theory that explicitly accounts for heterogeneous demand dynamics.

I believe Hunt is absolutely on the right track in his attempt to construct a complex, multi-level story of the influence of the so-called "informal," but all-important institutional structures of society on the overall wellbeing of society. It also makes much sense to link this work to work in moral philosophy, notably descriptive ethics. Ethics is, of course, a perennial classic of philosophy, and any moral philosopher worth his salt has been aware of the social functions and ramifications of ethics. Finally, I agree that understanding the influence of morals on wealth creation requires that attention be paid to the dynamic nature of competition. Thus, I do not register any disagreements with Hunt on the overall level. (I may disagree here and there on interpretive issues, e.g., in connection with neoclas- 

tan" norms, this relationship furthers trust and may save resources to the extent that Samaritans and other benevolent institutions of civil society can substitute for an often inefficient state apparatus financed by growth-reducing taxes. Helping behaviours entail that information and knowledge, for example, is effectively shared and transmitted at low costs to the benefit of the growth process. Other aspects of the ethical matrix may also positively influence growth. As Hayek (1973) observed, generalised norms that recommend celibacy (e.g., the American Shakers) are not exactly conducive to long-run growth. Norms that encourage individuals to have more children are conducive to growth (ceteris paribus) because an increasing population allows for an increasing division of labour, which, as Adam Smith observed, is conducive to growth. Stable families and low divorce rates may also be conducive to growth, as both-parent families tend to be better positioned to handle investments in education and may produce offspring less prone to become criminals.

The discussion above suggests many reasons why we would expect prevailing ethical norms to influence economic growth. While these reasons may not (yet) be an integral part of the economics of growth, the relevance of moral norms for society-level economic performance has long been recognised in political philosophy and political economics and is increasingly recognised in social psychology and management research. With respect to the latter, a rather large number of papers, not the least in international business research, recognise that there is cross-country variation in ethical norms (e.g., Langlois \& Schegelmilch, 1990; Carroll \& Gannon, 1997). This fact is recognised in management research in fields that specialise in international human resource management and intercultural communication and competence. Most of these papers may not directly link societal ethical norms to economic performance, but some do. Thus, Franke and Nadler (2008) proffer an index that measures "national ethical attitude," which they define as people's "cognitive, affective, and behavioural predispositions to react to issues and activities involving social standards for what is morally proper and virtuous" (p.255). Such attitudes, in turn, derive from societal ethical norms. They link national ethical attitude, derived from the World Values Survey, to economic performance (GNP data) and show that national ethical attitude is a significant pre- dictor of cross-country variation in GNP. Franke and Nadler may thus be seen as offering an empirical counterpart to Hunt (2012) (although they do not make use of Hunt's ethical classifications when discussing crosscountry variation in ethical attitudes).

\section{Heterogeneous Resources and Transaction Costs}

Hunt's reasoning involves a complex interplay of micro and macro levels. As he (Hunt, 2012, p. 13) explains:

"If (at the micro-level) the primary objective of firms is superior financial performance (e.g. more profit than last year or a return on investment greater than one's competitors), but (at the macro-level) a key factor distinguishing wealthy from nonwealthy societies is trust-promoting institutions, the challenge for any theory of markets and any dynamic theory of competition within markets is to explicate the process by which such macro-level, trust-promoting institutions as moral codes can contribute to (or from) firmlevel, superior financial performance."

Hunt's seeks to explicate this process in terms of resource-advantage theory, building on the "foundational premises" of that theory, which are the following (Hunt, 2012, p. 14):

P1. Demand is heterogeneous across industries, heterogeneous within industries, and dynamic.

P2. Consumer information is imperfect and costly.

P3. Human motivation is constrained self-interest seeking.

$\mathrm{P} 4$. The firm's objective is superior financial performance.

P5. The firm's information is imperfect and costly.

P6. The firm's resources are financial, physical, legal, human, organisational, informational, and relational.

P7. Resource characteristics are heterogeneous and imperfectly mobile.

P8. The role of management is to recognise, understand, create, select, implement, and modify strategies.

P9. Competitive dynamics are disequilibrium-provoking, with innovation endogenous.

Hunt spends considerable time explaining these propositions and perhaps too little time explaining how exactly "R-A theory can explain how macro-level, trustpromoting institutions such as personal moral codes can contribute to (or from) firm-level, superior finan- 

This suggests that the elasticity of substitution is endogenous (Arrow et al., 1961). Although certain inherent technical constraints imply that resources will never be perfect substitutes, the aggregate elasticity of substitution is to a large extent endogenous to institutional variables. Certain institutions promote a high elasticity of substitution, which in turn implies high factor productivity because resources are more easily allocated to highly valued uses and new modes of organisation and new processes are more easily implemented. Underlying the positive impact on factor productivity of high elasticity of substitution is a high degree of certainty in dealings and, therefore, low transaction costs of searching for contract partners, bargaining, and monitoring and enforcing contracts. Huge literatures in economic history concerning intellectual property rights and innovation stress the importance of welldefined, enforced property rights for entrepreneurial activity at the micro level and economic development at the macro level (e.g., North, 1990). Well-defined and enforced property rights reduce the transaction costs of carrying out the entrepreneurial activities: Welldefined property rights imply that contracting costs are relatively low, which implies low costs of searching for, negotiating with, and concluding bargains with the owners of those inputs that enter into entrepreneurial ventures. In short, the transaction costs of processes of resource mobilisation and orchestration are low. Moreover, well-defined and enforced income rights imply that the risk of undertaking entrepreneurial activities is reduced, which may also stimulate the supply of entrepreneurship (Foss \& Klein, 2012). Bjørnskov and Foss (2012) test these arguments, focusing on formal institutional variables.

However, it seems clear that informal institutions - notably, societal ethical codes - can similarly influence the aggregate elasticity of substitution and, therefore, total factor productivity. Morals that support more formal institutions of property and ownership evidently play such a role. However, morals that support pro-social behaviours in general may also play an important role. An economy characterised by a great deal of helping behaviours, civilised manners, and the like is also likely to be an economy with little friction, controversy, and destructive disagreement - one that promotes flexibility and adaptability, leading to higher total factor productivity.

\section{Conclusions}

Shelby Hunt has produced a characteristically stimulating paper that seeks to extend his RA theory. It is one among a number of papers over the last few years that have tried to link the informal institutions of society to the growth process. The purpose of this comment has been to note that some of the key mechanisms in Hunt's new theory are deserving of elaboration. There are plenty of relevant insights from which to draw on in accomplishing this task.

\section{References}

Arrow, K. J., Chenery, H. B., Minhas, B. S., \& Solow, R. M. 1961. Capital-Labour Substitution and Economic Efficiency. Review of Economics and Statistics, 43, 225-250.

Barney, J. B. (1991). Firm resources and sustained competitive advantage. Journal of Management, 17(1), 99-120

Bjørnskov, C., \& N. J. Foss. (2012). How strategic entrepreneurship and the institutional context drive economic growth. Strategic Entrepreneurship Journal (forthcoming).

Bowles, S. (1998). Endogenous preferences: The social consequences of markets and other institutions. Journal of Economic Literature, 36(1), 75-111.

Carroll, S. J., \& Gannon, M. J. (1997). Ethical Dimensions of International Management. Thousand Oaks, CA: Sage.

Foss, N. J., \& Klein, P. G. (2012). Organizing Entrepreneurial Judgment. Cambridge: Cambridge University Press.

Franke, G. R., \& Nadler, S. S.. (2008). Culture, economic development, and national ethical attitudes. Journal of Business Research, 61(3), 254-264.

Glaeser, E., La Porta, R., Lopez de Silanes, F., \& Shleifer, A. (2004). Do Institutions Cause Growth? Journal of Economic Growth, 9(3), 271-303.

Hayek, F. A. (1973). Law, Legislation, and Liberty, Vol. 1: Rules and Order. Chicago, IL: University of Chicago Press.

Hunt, S. D. (2012). Trust, Personal Moral Codes, and the Resource-Advantage Theory of Competition: Explaining Productivity, Economic Growth, and Wealth Creation. Contemporary Economics 6(2), 4-19.

Klenow P.J., Rodriguez-Clare, A. (1997). The Neoclassi- 
cal Revival in Growth Economics: Has It Gone Too Far? NBER Macroeconomics Annual, 12, 73-103.

Klump, R., \& Grandville, O. de la. (2000). Economic Growth and the Elasticity of Substitution: Two Theorems and Some Suggestions. American Economic Review, 90(1), 282-291.

Knight, F. H. (1921). Risk, Uncertainty, and Profit. New York, NY: Augustus M. Lelley.

Lachmann, L. M. (1956). Capital and Its Structure (2nd ed.). Kansas City, KS: Sheed Andrews and McMeel.

Langlois, C. C., \& Schlegelmilch, B. (1990). Do corporate codes of ethics reflect national character? Evidence from Europe and the United States. Journal of International Business Studies, 21, 512-539.

Lindenberg, S., \& Foss, N.J. (2011). Managing Motivation for Joint Production: The Role of Goal Framing and Governance Mechanisms. Academy of Management Review 36(3), 500-525.

Lucas, R. (1988). On the Mechanics of Economic Development. Journal of Monetary Economics 22(1), 3-42.

North, D. N. (1990). Institutions, Institutional Change, and Economic Performance. Cambridge: Cambridge University Press.

Rodrik, D., Subramanian, A., \& Trebbi, F. (2004). Institutions Rule: The Primacy of Institutions Over Geography and Integration in Economic Development. Journal of Economic Growth, 9(2), 131-165.

Romer, P. (1990). Endogenous Technological Change. Journal of Political Economy 98(5), 71-102.

Solow, R. M. (1956). A Contribution to the Theory of Growth. Quarterly Journal of Economics, 70(1), 65-94.

Solow, R. M. (1957). Technical Change and the Aggregate Production Function. The Review of Economics and Statistics, 39(3), 312-320.

Temple, J. (1999). The New Growth Evidence. Journal of Economic Literature, 37(1), 112-156. 